\title{
Review for constitutional political economy of the book by George C. Bitros, Emmanouil M. L. Economou and Nicholas C. Kyriazis
}

\author{
London and New York: Routledge 2021. XXII + 298 pp, ISBN: \\ 978-0-367-50917-0 (hbk); ISBN: 978-1-003-05180-0 (ebk)
}

\section{Bertram Schefold ${ }^{1}$ [D}

Accepted: 7 May 2021 / Published online: 25 May 2021

(C) The Author(s) 2021

This book is a passionate plea to establish private free banking in the framework of a direct democracy, primarily addressed to the United States of America, on the basis of theoretical arguments taken from monetary economics and political science and based on a model economy: ancient Athens in the classical period. The ideal is at a distance of 2500 years. The authors manage the balancing act as economists, who all have published on ancient economic history. George Bitros is also a senior government advisor. All seem united in their love for the subject, but they are well aware that ancient economic history has become a field for specialists, and so they dedicate their book to the "many scholars of the ancient Athenian society and economy on whose contributions particularly in recent decades this book has been based". Where evidence often is extremely scanty, there is always the temptation to substitute historical fantasy, constructing a coherent picture in order to defend what in the end still is a rather utopian project. Perhaps I should confess where I stand myself. I am a theoretical economist who happens to have an intense interest in the ancient economy, but more from the side of the history of economic thought than economic history. I have actively participated in the Swiss direct democracy, voting, whenever I could, on all sorts of issues and taking part in elections-if abroad, by mail—and the monetary system fascinates me like every other economist, but my education in the matter was Post-keynesian. This may justify differences of interpretation and perspective.

The book is organised in nine chapters. The Introduction is important, because it defends the unusual project of improving the modern monetary system by seeking inspiration from a comparison with the economy of ancient Athens. Chapter 1

Bertram Schefold

schefold@wiwi.uni-frankfurt.de

1 Faculty of Economics, Goethe University, Theodor-W.-Adorno Platz 4, 60323 Frankfurt, Germany 
explains the classical monetary system from mining and the minting of silver to the banks, the money changers and the pawnbrokers. Incomes and expenditures of the Athenian state, the balancing of the budget and the control of the magistrates, together with the question of whether there was a lender of last resort, are analysed in the third chapter. Chapter 4 deals with monetary policies on the basis of three historical examples, of which we are sufficiently well informed to reconstruct the sequence of events. Chapter 5 describes the structures of the state sector and the private sector, including handicraft, shipping and education. Chapter 6 attempts to model the money and credit markets. The discussion then moves to an assessment of the comparative performance with regard to price stability, employment and growth of the Athenian and the American economy, looking at both from an internal and an external point of view. Chapter 8 asks what alternatives to common modern central banking existed in history and attempts to prove that free banking is to be preferred. Chapter 9 relates the economic to the political institutions and argues that control by means of direct democracy is superior to a system of representation, combining the historical experience with propositions of modern political economy. There are ample references to ancient and modern authors, and a glossary of Greek terms helps to identify the ancient institutions.

There is no question that the Athenians practiced a radical form of direct democracy in that important decisions were taken in a popular assembly of the male citizens, as has been the case in some Swiss cantons for eight centuries. In Athens, there also was the council of 500, with 50 delegates from each tribe, and there were the popular courts. The activities of magistrates, some elected, some chosen by lot, were closely supervised. Direct democracies_and at any rate the Athenian-tend to be prudent in borrowing. They could borrow from the temples, and it seems that the temples deposited part of their funds with private banks. The latter were not abstract juridical entities, but consisted in the person of a banker, assisted perhaps by some slaves, and they lent to private individuals. The activities thus undertaken could be in agricultural estates - then the rate of interest could be low, no doubt because of the securities involved — or to trade. Maritime loans carried high interest on account of the risk. Money in the narrow sense then consisted in minted silver coins. The Athenian economy thrived when silver was flowing in from the mines or when the allies were paying their tributes in what could be called the Athenian empire. The expenses on infrastructure and the fortifications, on temples and theatres, were only to a moderate extent and not for long periods based on borrowing, but on income of the state, derived from harbour taxes and other sources. And the mint, the authors argue, was not a central bank lending to the public, but the producer of coins - money in the narrow sense - that everybody could get minted at a low cost, because seigniorage was modest. A model of demand and supply of money then is constructed, in which bullion is money in a wider sense, and which also contains credit, for we know that payments could be made using paper resembling bills. Treasures could be kept in the form of foreign coins that were hardly used in circulation, or as silver vessels. The model the authors propose seems to me quite similar to what authors of the sixteenth and seventeenth century had in mind in northern Europe, such as Copernicus or the authors of the Saxon debate on coinage. If the mint had produced too many coins - this was called "over-minting" (Übermünzung) 
- it would pay to melt down the coins and to use the silver as ornament or to export them, even if it was forbidden (Schefold, 2016). Such episodes are not known to us, as far as ancient Athens is concerned, perhaps because melting down the silver was not forbidden, so that the spread between the purchasing power of the silver contained in the coin and of the coin as coin was never large enough to justify such a measure at a noticeable scale.

The freedom of banking for private persons and the absence of imprudent borrowing on the part of the organs of the state are the two main reasons why the economy of ancient Athens is taken as a model for the most advanced economy of the modern world. The authors justify their bold comparison by means of political arguments that bear on the logic of direct democracy on the one hand and that of representative democracy on the other. Building on Schumpeter and more recent positions of political economy, they argue that politicians in representative democracies pursue their own agendas and deviate in so doing considerably from interests of the voters. Deficit spending and lax policies of the central bank, that made financial crises of increasing severity possible, have led to a perilous situation, in which the central bank is not able to control the money supply, nor even interest rates.

Whether this Hayekian diagnosis is correct, whether it is feasible to return to a gold standard or to a commodity standard such as has been proposed by Triffin or Kaldor long ago, whether a modern form of free banking based on electronic currencies, accompanying a commodity-based currency issued by the state, are questions that are discussed at some length in this book, while there is not much room for the alternative perspective according to which the excess of saving over investment is due to the demographic situation and the world is waiting for a new technological wave, which would help to overcome near stagnation.

The message of the book is sufficiently important and controversial to generate discussion, but its main originality is in the analysis of the Athenian economy and society. It is more built on secondary sources - the said scholars of ancient historythan on an original reading of the primary sources - the quotes one finds are mostly those one knows from elsewhere. Among the secondary sources, Cohen's book on banking (Cohen, 1992) stands out. The book can be useful for any economist, in any domain, who wishes to enlarge his or her historical knowledge in order to get a better idea of the contingency of modern institutions. However, I think that the modernity of the Athenian economy is here overstated. The book mentions the fact that a controversy between so-called primitivists and so-called modernists has been going on in the discussion about the ancient economy ever since the late nineteenth century. In the beginning, it was confined to Germany, with Karl Bücher, a leading liberal member of the German historical school as the primitivist, and the scholars Eduard Meyer and Julius Beloch as the modernist historians. Meyer would measure the modernity of the Athenian economy by comparing it to the state of development of technology and commerce in Europe in the fifteenth and sixteenth century, while Beloch would speak of big industry and an economy centred on exports to the entire ancient world. Bücher had emphasised agrarian household production, a different rationality and limited extension of trade. Finley (1979) published this debate in German and brought it to life in a number of books. While primitivism prevailed in the 1980's, ancient history has moved towards a more modernist position since, but 
the book under review suppresses too many of the primitivist insights, in my view. It does not make much of the liturgies, that is, the voluntary donations by rich citizens to the state, for which the providers received no other return than honours, when they financed the maintenance of a warship (Trireme) or a contribution to a theatrical performance (Choregia). But such solidarity was essential for direct democracy in ancient Athens; it consisted in more than formal constitutional rules. Or take the familiar point emphasised by Max Weber: in premodern times, households are the only producing units. It is not difficult to imagine situations in which the aims of the head of the household, insofar as he is a father, collide with his aims, insofar as he directs a business, and this same person also has responsibilities as a citizen and warrior of the state. Weber therefore thought that a pure capitalist rationality could only develop, once household and firm became separate entities, in the late middle ages, and this, for him, was only one of the conditions necessary for the development of modern capitalism.

The decidedly modernist stance taken by the authors of this book diminishes its value to some extent, but it remains a comprehensive, useful and timely collection of what we know today of the Athenian economy and provides challenging arguments on how we might use the wisdom thus gained for future reforms. The combination of different disciplines, the wealth of information provided, the bold policy proposals are remarkable and represent a singular achievement.

Funding Open Access funding enabled and organized by Projekt DEAL.

Open Access This article is licensed under a Creative Commons Attribution 4.0 International License, which permits use, sharing, adaptation, distribution and reproduction in any medium or format, as long as you give appropriate credit to the original author(s) and the source, provide a link to the Creative Commons licence, and indicate if changes were made. The images or other third party material in this article are included in the article's Creative Commons licence, unless indicated otherwise in a credit line to the material. If material is not included in the article's Creative Commons licence and your intended use is not permitted by statutory regulation or exceeds the permitted use, you will need to obtain permission directly from the copyright holder. To view a copy of this licence, visit http://creativecommons.org/licen ses/by/4.0/.

\section{References}

Cohen, E. (1992). Athenian Economy and Society. Princeton University Press.

Finley, M. I. (Ed.). (1979). The Bücher-Meyer Controversy. Arno Press.

Schefold, B. (2016). Great Economic Thinkers from Antiquity to the Historical School Translations from the Series Klassiker der Nationalökonomie. Routledge Studies in the History of Economics, 178. London, New York: Routledge.

Publisher's Note Springer Nature remains neutral with regard to jurisdictional claims in published maps and institutional affiliations. 